\title{
Innovated Technologies of Recycling of Metallic Wastes - Modification of Existing Industrial Processes
}

Silvie Brožová, Pavlína Pustějovská, Jiř́ Bilík, Simona Jursová, Monika Zbranková, Jaroslav Havránek VŠB-TUO, Technical University of Ostrava, Czech Republic

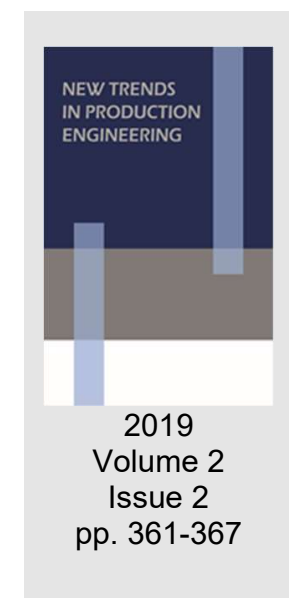

Date of submission to the Editor: 09/2019

Date of acceptance by the Editor: 11/2019

\section{BLAST FURNACE SMELTING MODIFIED}

Modified blast furnace smelting results from former Russian project of nitrogen free blast furnace supplemented by new knowledge of $\mathrm{CO}$ recycling. Only two options of $\mathrm{CO}$ addition were projected: only through tuyeres and option of $\mathrm{CO}$ addition through tuyeres and to the lower part of the saft. Research was carried out mostly in Sweden in Lulea region where the research is concentrated in Lulea University of Technology and Institute for Metallurgical Research as well as in Luossavaara-Kirunavaara $A B$ plant at the model blast furnace of capacity amounting to $8.2 \mathrm{~m}^{3}$ with 3 tuyeres.

Six-week tests in year 2007 have confirmed following facts:

- practical possibility to run smelting arranged in this way,

- possibility of continuous and stable course of processes,

- possibility of even $24 \%$ saving of carbon during iron production (1-9).

This group of technologies includes also 3 final research proposals of ULCOS programme and to a certain extent also the research intend of Trinecké železárny, a.s. called TROP solved in the past which could have resulted in massive recycling and exploitation of metallic wastes, including application of wastes as a fuel and deoxidizing agent (Baricova, 2002, Brozova \& Pustejovska, 2009, Janik et al., 2008, Leimalm et al. 2008).

\section{PRIMUS Technology - Paul Wurth}

PRIMUS process developed at Paul Wurth S.A. company serves for economic elaboration and ecologic recycling of wastes during production of pig iron and steel:

- recycling of dusts and slags generated at blast furnaces and converter steel work with extraction of iron, zinc and other non-ferrous metals,

- process is based on combination of two-hearth furnace with special equipment of electric arc, 
- coal serves as a deoxidizing agent and energy resource (Knepper et al., 2012, Roth et al., 2001, Król, 1983).

Diagram of technology, individual aggregates of the complete equipment as well as the method of extraction of special-interest metals are demonstrated on the following (Fig. 1, 2).

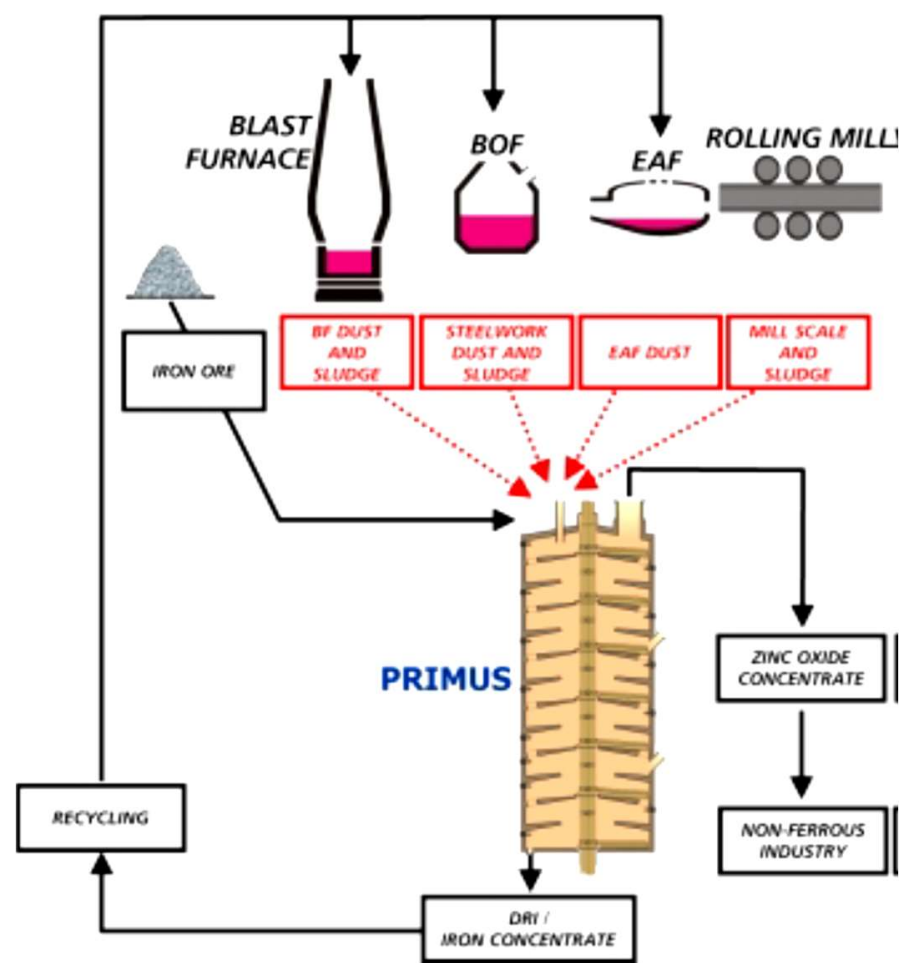

Fig. 1 PRIMUS Treatment of steelmaking by-products Source: (Knepper et al., 2012, Roth et al., 2001, Król, 1983)

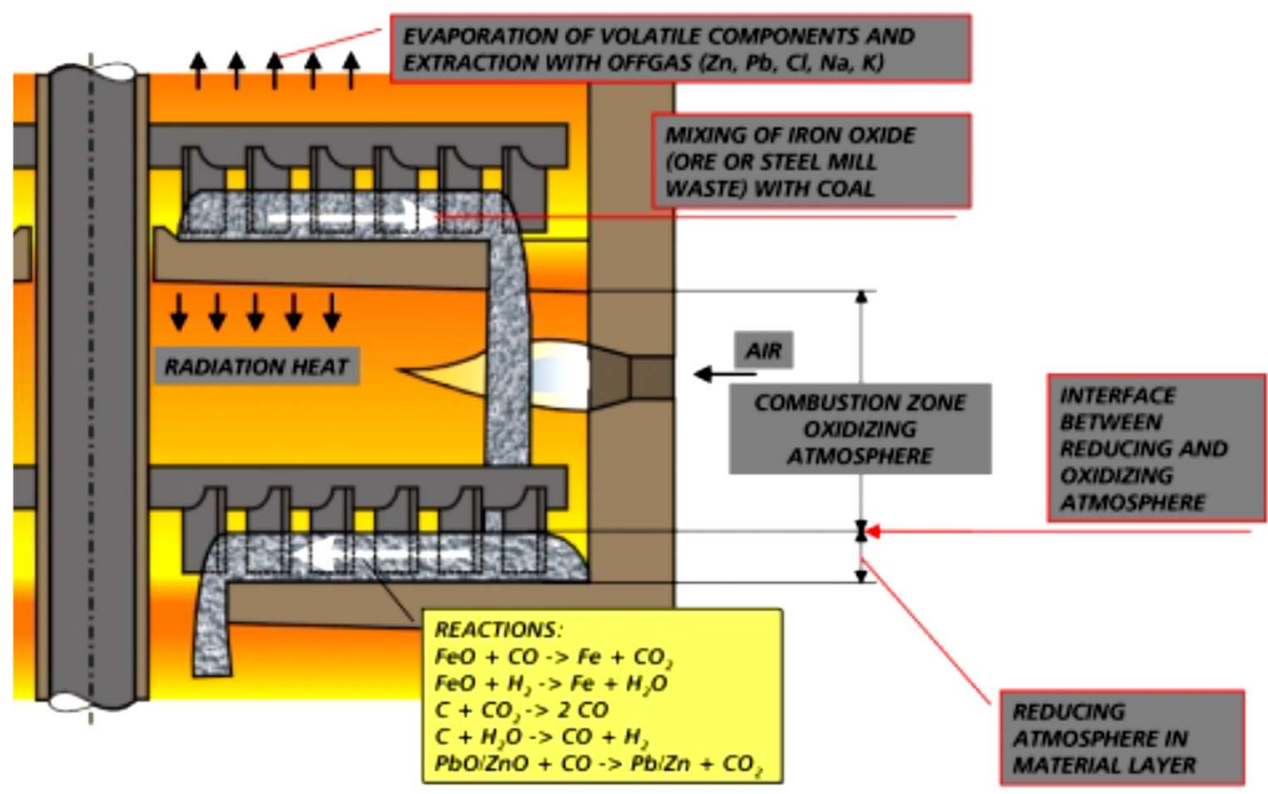

Fig. 2 Process metallurgy PRIMUS

Source: (Knepper et al., 2012, Roth et al., 2001, Król, 1983) 


\section{ISARNA - INTENSIVE MELTING DEOXIDATION}

Published diagrams of this process of melting deoxidation resemble with its arrangement a combination of principles of CCF process (developed in cooperation with British Steel, Corus, Ilva and Romelt and further elaborated in MISIS, Moscow) (LeilmIm et al., 2008, Knepper et al., 2012, Roth et al., 2001, Król, 1983, Dry \& Bates, 1999, Hlsmelt, 2014, Research Reports, 2014, Birat et al. 1993, Birat, 2008, www.wolrdsteel.org, 2007, Pustejovska et al., 2014, Findorak et al., 2013, Dzupkova et al., 2011, Bernasowski, 2014, Baricova et al., 2013, Frohlichova et al., 2015).

The basic scheme of ISARNA process is shown on (Fig. 3).

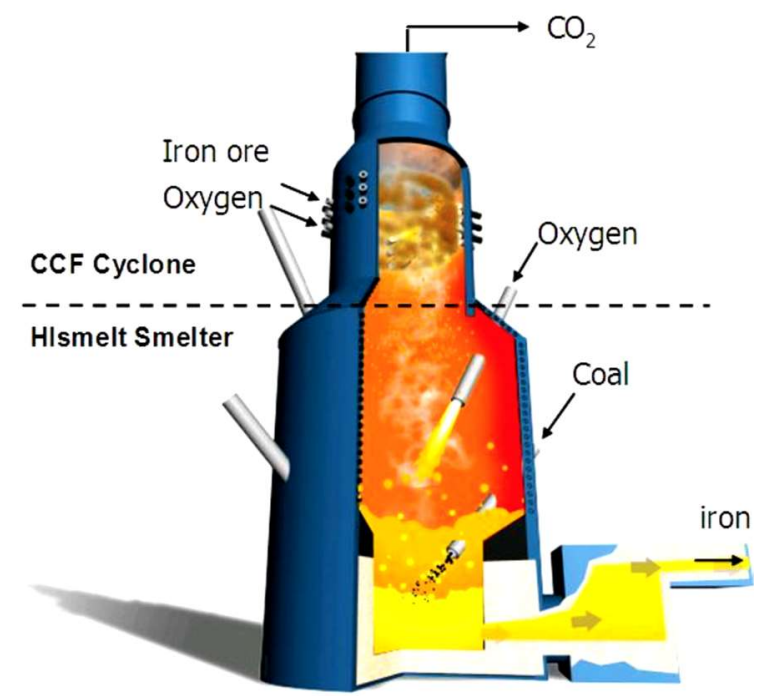

Source: (Birat et al. 1993, Birat, 2008)

Fig. 3 Basic diagram of ISARNA process

Reactor is internally divided into two parts. Into upper cyclone level there is tangentially brought oxygen and iron ore which is heated and pre-oxidized in the stream of process gasses burnt by oxygen at the same time. Ore and oxygen enter in several height levels. Pre-oxidized ore falls into the lower melting level and pre-heated coal and/or semi-coke, slag-making additions and oxygen is brought here. Main reactions run in the slag zone and pig iron and slag are discharged from the lower part.

The main advantages of the process are as follows:

- there is no need of preliminary treatment of ore or coke,

- flexibility of using a fuel (biomass, natural gas, hydrogen),

- outgoing gas is rich in $\mathrm{CO}_{2}$ and it makes its washing easier.

\section{TROP PROCEDURE}

The inspiration for development of the process was information on following procedures:

- IFCON - setting of pre-oxidized ore and slag with subsequent oxidation fining at ISCOR company, Republic of South Africa,

- OXICUP - self-oxidation briquettes of oxide and shaft furnace ThyssenKrupp Steel AG, Küttner GmbH, Germany, 
- ECOARC - pre-heatment and srap melting at electric furnaces of NKK Steel Engineering, Japan (www.wolrdsteel.org, Pustejovwska et al., 2014).

For comparison there is also drawn up basic information on research and development of Třinec experiment of TROP procedure (melting deoxidation oxidation process). Purpose of the project was a development in the field of direct steel production from the scrap and briquettes of metallurgical wastes with fuel addition, lime addition and bonding agent at adapted cupola completed with melting and reaction area heated with gas burners - see following (Fig. 4).

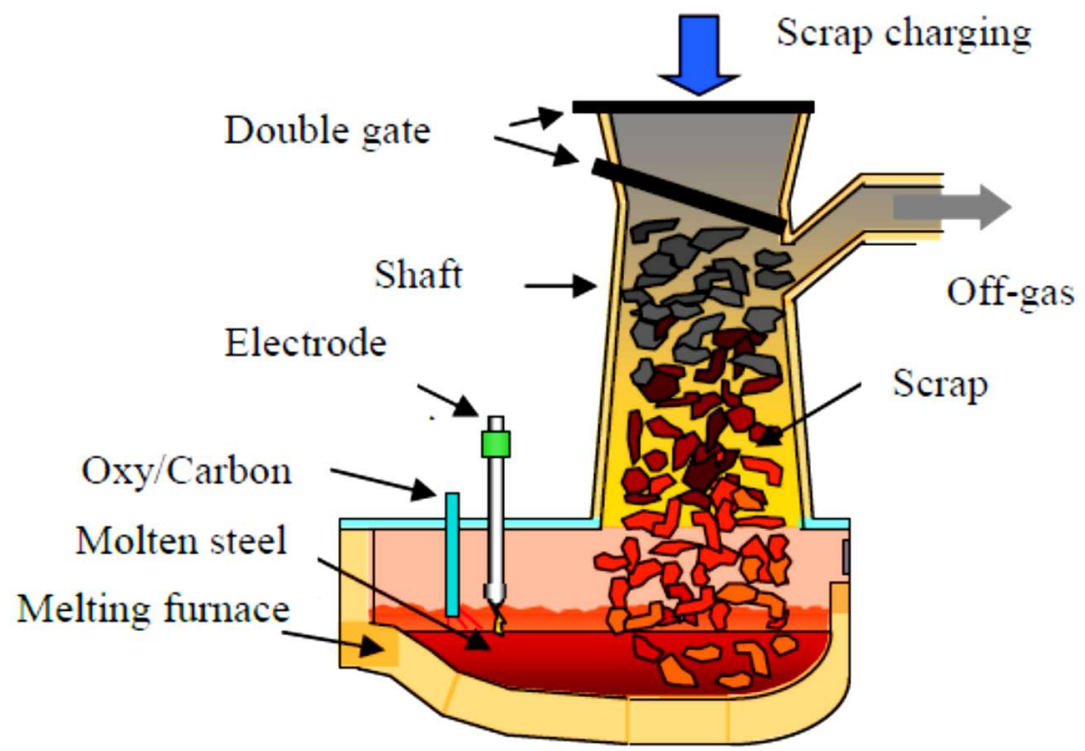

Fig. 4 Concept diagram of ECOARC ${ }^{\mathrm{TM}}$

Source: (www.wolrdsteel.org, 2007)

Charge consisted of the mixture of scrap and metallurgical wastes in the form of briquettes, with relevant carbon content which corresponds to its consumption on deoxidation. Procedure technology should have consisted in throughput of carbon enriched briquettes where this carbon should have deoxidized oxides of iron. At the same time steel waste was throughput and it was heated by flue counter-flow from reactor part of the equipment.

Pre-oxidized briquettes and pre-heated scrap were melted by oxygen burners during eventual coal injection for final deoxidation, melting down and overheating. Desulphurization should have been attained by control of $\mathrm{FeO}$ content in the slag.

Charge in solid state at deoxidation zone is reduced by gas for up to Fe. Reducing gas is added only in case when its amount from fuel burning is not sufficient. Mixture of scrap and reduced out waste are melted and pre-heated upto $1650^{\circ} \mathrm{C}$ in melting zone where the temperature is kept by fuel combustion (coal or hydrocarbons) through oxygen or pre-heated air. In the lower part slag and crude steel is separated. Slag with approx. $20 \% \mathrm{FeO}$ and high basicity is discharged continuously, while crude steel is discharged periodically.

In partial conclusion we can compare the process with blast furnace through basic principles as follows:

a) Function of skeleton construction is replaced by slag throughput, 
b) Fuel function is realized by coal or hydrocarbon combustion,

c) Function or deoxidizing agent is realized through reducing gas:

- from gasification equipment blown on the shaft,

- arisen from fuel burning in the lower furnace part.

Possible problems:

- scrap softening and worse permeability of the charge column,

- high share of gas deoxidation does not enable exploitation of decrease of gas and fuel owing to carbon deoxidation,

- heat delivery in the lower furnace part requires partial combustion to $\mathrm{CO}_{2}$ and it reduces reducing gas potential in the upper furnace part,

- lower unit capacity and a number of accompanying equipments result in increase of fixed costs,,

- higher metal losses from slag add to the costs on charge

- higher velocity of the air flow at the shaft can result in a higher emission,

- lower life time of refractory material and thereby higher variable costs.

Adding of self-oxidation briquettes into charges have shown itself by the decrease of $\mathrm{Mn}$ and $\mathrm{Si}$ content in the alloy as well as by the decrease of temperature of fluid metal in ladles. All fluid metal was used for the foundry shop purposes either directly or after the treatment at electric holding furnace.

The amount of generated slag ranged up to $10 \mathrm{~kg}$ per $100 \mathrm{~kg}$ of metal charge. In this case briquettes ( $40 \%$ of $\mathrm{Fe}$ in briquette) were the main resource of oxides of iron in slag generated in this way. Deoxidation of these oxides is possible mainly due to the contact of re-hot coke and carbon in briquettes. The oxidation grade of oxides of iron can be approximately evaluated by relation between the amount of iron brought by briquettes and the amount of iron in slag. There is an important condition for essential increase of briquette share in charges and thereby even increase of the amount of reduced out metal and this is an increase of heat input of the cupola, preferably by oxygen intensification. The main positive seemed to be $100 \%$ exploitation of cast metal as well as slag character which did not include any addition of undesirable components.

Course of experimental heats was problematic and even though number of measures, including changes of reactor geometry had been suggested, it was decided not to continue in works and to stop the research.

As failure causes can be considered to be following factors:

- failure of production of self-consistent oxide briquettes which lack desirable properties,

- insufficient laboratory and model verification of partial processes,

- prevalence of steel knowledge over the blast furnace knowledge resulting in disobedience to recommendations from understanding processes of reduction, softening, melting and convection in relation to permeability as well as to the questions of kinetic energy of flue gases in front of burners,

- out of system solutions of problems arising during experiments with the pilot equipment (high temperature of flue gases, uneven smelting, failure in connection of melting zones, irregular fall of charge, loss of the charge column permeability, low temperature of metal, considerable foaming of slag) 
(Findorak et al., 2013, Dzupkova et al., 2011, Bernasowski, 2014, Baricova et al., 2013, Frohlichova et al., 2015).

\section{ACKNOWLEDGEMENT}

The article has been prepared in frame of the Project No. L01203 "Regional Materials Science and Technology Centre - Feasibility Program" funded by Ministry of Education, Youth and Sports of the Czech Republic and the project No. SP 2017/77, SP 2018/100.

\section{REFERENCES}

Baricová, D., (2002). Recycling of oxygen converter flue dust into oxygen converter charge, Metalurgija, vol. 41, no. 3, p. 242.

Baricova, D. et al., (2013). Steelmaking slag - waste or valuable secondary raw material, Conference Proceedings 13th International Multidisciplinary Conference SGEM, pp. 437-442.

Bernasowski, M. (2014). Theoretical Study of the Hydrogen Influence on Iron Oxides Reduction at the Blast Furnace Process, Steel Research International, Germany, vol. 85, no.4, pp. 670-678.

Birat, J. P., Antoine, M., Dubs, A., Gaye, H., (1993). "Vers une sidérurgie sans carbone?", Revue de Métallurgie, vol. 90, pp. 411-421.

Birat, J.P., (2008). Steel and $\mathrm{CO}_{2}$ - the ULCOS Program, CCS and Mineral Carbonation using Steelmaking Slag, 3rd International Conference on Process Development in Iron and Steelmaking, 8-11 June 2008, Luleå, Sweden

Brožová, S, Pustějovská, P., (2009). Jiné možnosti zpracování kovonosných oxidických odpadů s využitím plazmového ohřevu, Odpadové fórum 2009: sborník přednášek. Praha: PCHE - PetroChemEng, pp. 3292-3253.

Dry, R.J., Bates, C.P., Price, D.P., (1999). Hlsmelt - comprtitive hot metal from ore fines and steel plant wastes, METEC Congress 99, Düsseldorf 14-15 june.

Džupková M. et al.(2011). Evaluation of selected technological and ecological parameters of sinter production, Acta Metallurgica Slovaca, vo. 17, no. 4, pp. 26927.

Findorak R. et al., (2013). The effect of charcoal addition on iron-ore sintering emission, Conference Proceedings $13^{\text {th }}$ International Multidisciplinary Conference SGEM, pp. 629-636.

Fröhlichová M. et al., (2015). Influence of biomass on the structure of iron ore sinter, Conference Proceedings $15^{\text {th }}$ International Multidisciplinary Conference SGEM, pp 615-620.

Hlsmelt [10.5.2014] http://www.riotinto.com/ironore/hismelt-4724.aspx

Janík, I., Bilík, J., Kret, J., Brožová, S., (2008). Koncept př́mé výroby oceli bez emisí skleníkových plynů, Dílčí zpráva rozvojového záměru MŠMT: DeCOx - Snížení emisí CO2 v metalurgii. Ostrava.

Knepper, M., Babich, A., Senk, D., (2012). Reaktionskinetic von Reduktionstragern im Hochofen und Schmelzvergaser, Tagungsband 27. Aachener Stahlkolloquium, Eurogress Aachen 2012, pp. 85-96.

Król, L. (1983). Redukcja bezprosrednia rud zelaza, Katowice: Slask 1983, s. 219.

Leimalm U., Ökvist, L.S., Björkman, B. (2008). Effect of Different PCI Practice on the Texture Obtained during Reduction of Iron Oxide Pellets, ISIJ International, Vol. 48, No. 12, pp. 1686-1695.

Pustějovská, P., Kardas, E., Jursová, S., Ingaldi, M., Brožová, S., Konstanciak, A. (2014). Nové metody zpracování a recyklace jemnozrnných kovonosných odpadu, Hutnické listy vol. LXVII, no.1, pp. 24-28.

Research Reports

[10.5.2014] http://www.purdue.edu/discoverypark/energy/CCTR/researchreports.php 
Roth, J.L., Frieden, R., Hansmann, T., Monai, J., Solvi, M. (2001). Primus, a new proces for recycling, by-products and producing virgin iron, La Revue de Métallurgie - CIT November 2001, p. 987.

Fischer-Tropsch Processing (FT) Indiana Center for Coal Technology Research, June 2007. http://www.purdue.edu/dp/energy/CCTR/www.worldsteel.org

\begin{abstract}
.
This paper describes interesting operational experiments have been performed in the scope of the project where the process of melting deoxidation was used under improvised conditions of cold blast cupola furnace. The goal was to find out metallurgical effects of added selfreducing briquettes prepared from steel sludge into cupola furnace charge and above all to verify the grade of deoxidation of oxides of iron at keeping output quality of cast metal. Present state of research and development of technologies of iron production in the area of commercial exploitation of these technologies is not in such a position that we could realistically assess their efficiency, investment costs and economic impacts. Moreover, an unequivocal requirement on minimization of $\mathrm{CO}_{2}$ emissions, mainly by its recycling, is here more and more promoted.
\end{abstract}

Keywords: technologies, iron, wastes 